\title{
IMPACT OF SOCIO-DEMOGRAPHIC CHARACTERISTICS ON TRAVEL EXPENDITURES OF HUNGARIAN TOURISTS IN THE VILLAGE OF SKORENOVAC
}

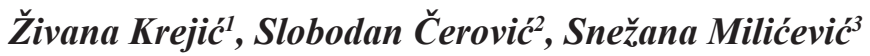

\begin{abstract}
Summary
Development of rural tourism in Vojvodina affects the survival of village and livelihoods of its people. Despite the numerous problems that villages of Vojvodina face, an example of good practice is the village of Skorenovac in the municipality of Kovin in Banat. Local culture, traditions and legends of the distant past, and a unique way of life of the population of this village are the primary motives and grounds of the arrival of tourists and they affect the development of rural tourism. The aim of this study was to determine whether there are differences in the consumption of Hungarian tourists in the village Skorenovac in relation to age, level of education and gender. The results of research should serve as encouragement of rural households to monitor socio-demographic characteristics of tourists to suitably form the tourist offer in order to increase profit.
\end{abstract}

Keywords: socio-demographic characteristics, rural tourism, Hungarian tourists, Skorenovac, consumption.

JEL: $Q 1, L 83, Q 18$

\section{Introduction}

From the earliest times to the present day, cultural motives were the primary motives that encouraged people to travel. A certain degree of cultural development in a society increased the likelihood of organization of first travels, as it was in Egypt, Mesopotamia, Babylon, Persia, Ancient Rome, Ancient Greece, and so on (Goeldner, Ritchie, 2009).

1 Živana Krejić M.A., Ph.D candidate, University of Singidunum, Faculty of Tourism and Hospitality Management, Danijelova street no. 32, Belgrade, Serbia, Phone: +381 66900 78 78; E-mail: zkrejic@yahoo.com

2 Slobodan Čerović Ph.D., Full Professor, University of Singidunum, Belgrade, Danijelova street no. 32, Phone: +381 1130932 10, E-mail: scerovic@singidunum.ac.rs

3 Snežana Milićević Ph.D., Assistant Professor, University of Kragujevac, Faculty of Hotel Management and Tourism in Vrnjačka Banja, Vojvođanska Street no. 5A., 36210 Vrnjačka Banja, Serbia, Phone: + 3813651500 24, E-mail: snezana.milicevic@kg.ac.rs

EP 2016 (63) 2 (601-615) 
Ever since tourism has become a global phenomenon, in recent decades there are evident changes in the tourist demand. Classic destinations and travel motives are changing. A way is given to new, specific forms of tourism, which also include rural tourism.

According to the World Tourism Organization (UNWTO), rural tourism is complex and is divided to several segments: natural and rural environments (rivers, lakes, forests), rural cultural and spiritual features (architecture, churches, monasteries), ethno tourism (which includes traditional food, music, souvenir shops) and rural activities such as horseback riding, hunting and fishing (Prentović et al., 2012).

Europe is in the last 20 years the world's leading provider of rural tourism. European Federation of Rural Tourism - Euro Gites (European Federation of Rural Tourism) represents 27 member states, including the Serbia (Milićević, Podovac, Čavlin, 2015).

Authors Ruth, Donagh (2011) emphasize the importance of rural areas as complexes with multipurpose capabilities and their capacities for development of various interest groups.

Muhi and Jovanović (2012) pointed out that the rural tourism is an important component of integrated and sustainable development and revitalization of villages, as well as an important factor in encouraging the development of local agricultural and nonfarm activities in rural areas and villages; what is more, it is a substantial incentive to employment.

The fact that the traditional festivals, events and folklore artistic performances are an important part of rural tourism is also confirmed by Grossman (2013) in his book Shaping the Image and Perception of Japan's Folk Tradition. His research has shown that the historical motives such as legends, castles, festivals, folk traditions and different rituals are important elements for decision-making of tourist for traveling.

Addendum to this claim is the research of group of authors (Wanda et al., 2009) which has shown that the past is an integral part of cultural tourism. The tradition of the local culture and the unique way of life of its population, inherited cultural and architectural heritage are subjects of tourism demand. According to the same authors, this type of tourism has many positive effects, among which above all one should highlight employment opportunities, preservation of cultural heritage, its monuments, but also the preservation of languages, traditional crafts, traditional foods etc.

The importance of rural tourism development in China is highlighted in the research work Rural Tourism in China (Baoren, 2011) especially in terms of socio-economic revival of China.

Domestic authors (Bošković et al., 2013) emphasize the advantage of rural areas of Vojvodina for the development of cultural heritage among other things.

On the other hand (Štetić et al., 2014) they emphasize that rural tourism is associated with economic, social, cultural, natural and human resources. They also point out that numerous factors affect the implementation of integrated tourism in rural areas. 
The aim of this paper is to present the results of research based on survey data obtained from Hungarian tourists in the village Skorenovac and to encourage the local community to enrich its tourist offer and observe socio-demographic characteristics of tourists in order to encourage consumption.

As the influence of cultural motives on the development of tourism increased through time especially when it comes to economic effects, the paper investigated the motives that were crucial for the arrival of tourists to the village of Skorenovac, the average expenditure, the reasons which affected the expenditure, with the aim to encourage the underdeveloped rural areas to follow the example of this village for the development and achievement of the economic effects of tourism.

\section{Research Methodology}

The data in the paper were collected by direct research. The sample consisted of tourists from Hungary who stayed in the village of Skorenovac during the May Day holidays in 2015. A total of 75 tourists were surveyed.

By applying appropriate research methods (Kruskal-Wallis and Man-Whitney test), the variables included in the survey were related to: motives of tourists' arrival, how they have learned of this place (marketing before the start of travel), their satisfaction with the quality of service provided as well as the ratio between price and quality, the distribution of spending in relation to gender and the like.

Man-Whitney test was used in the research to test differences between the two variables: gender/expenditure (Did men and women spend money on this trip equally?). The obtained values are converted to ranks and it is then calculated whether these ranks significantly differ. The main values within this test are significance level and approximation.

The main hypothesis of the paper is that socio-demographic characteristics of tourists influence their consumption and that the analysis of these characteristics should be used as a basis for the development of tourist offer with the aim of increasing tourist spending. Within this hypothesis, three auxiliary hypotheses were also investigated, one of which is related to the expenditure of tourists in Skorenovac: with the premise that the expenditure of tourists is related to their age, that is, that expenditure level is neither linked to the level of education, nor the gender of a tourist. In the survey on tourist spending, has been reported and whether the level of education of tourists can affect the level of spending on their destination.

Data obtained in the survey were entered and analyzed using Statistical Package for the Social Sciences (SPSS) for Windows Release 21.0.0, which allowed drawing conclusions.

\section{Cultural motives as factors of development of rural tourism}

Cultural tourism is one of the oldest forms of travel. Due to the different motives that comprise it, this type of tourism has direct impact on tourism demand and initiates the development of other types of tourism. 
Different classification of cultural resources usually involves cultural and historical monuments, architectural objects, ethnographic and monastery complexes, churches, museums, monuments, exhibitions, galleries and various cultural attractions (Mrkša, Gajić, 2014).

Richards and Munster (2010) consider that it is difficult to distinguish between "culturally motivated" tourists and other travelers, due to the growing tendency towards different holiday motives.

However, an increasing number of arrivals and overnight stays of Hungarian tourists to the village of Skorenovac (the municipality of Kovin, South Banat region, the wider area of Vojvodina) was a motivation to conduct research on whether the cultural motives were the only reason for their arrival, but also to show that they are the basis and impetus for the development of rural tourism in this small settlement.

In this regard, the main objective of this paper is to show that the main reasons for the arrival of Hungarian tourists in the area of South Banat are cultural and historical motives, thanks to which cultural and rural tourism are developed i.e. that the multiculturalism in Vojvodina is extremely important and can favorably affect the development of tourism, i.e. it may be a decisive factor in the tourist travels and the achievement of economic effects from tourism.

For many countries around the world, the growth and development of tourism carry with them many positive and negative consequences. When it comes to rural tourism, it can be concluded that this form of tourism is of great importance for employment of the population, job creation and the overall economic development of rural areas.

To begin with, rural development has a profound influence on the development of rural tourism industry, i.e. the establishment of small and medium enterprises. In the US, $99 \%$ of all facilities related to tourism in rural areas qualify as small businesses; in the New Zealand, tourism industry is estimated to consist of between 13,500 to 18,000 small and medium-sized businesses, while in Israel rural tourism is based on small family businesses that employ up to three employees (Derek et al., 2005).

Rural tourism in Vojvodina can be an incentive for the development of small and underdeveloped communities, that thanks to tourism, they could contribute to a significant transformation of the society and the economy as a whole.

The demand for rural tourism has grown over the last years and the market does not seem to be saturated yet (Pesonen et al., 2011).

\section{Motives as primary values and decision factors for travel}

Based on a survey which included 75 tourists, with respect to the primary values in the tourism value chain in Skorenovac, the following conclusions were drawn.

When asked ,what was the motive of your arrival in the village of Skorenovac?", as many as 50 respondents $(66.67 \%$ of the total number of tourists) responded that 
their travel is related to the culture and history of the Hungarian people in the past. 12 respondents $(16 \%)$ responded that the reasons for coming were to taste traditional Hungarian dishes in this town, while six people (8\%) indicated that they decided to take this trip because of excursions organized in Romania which are also associated with the history of the Hungarian nation. Seven respondents specified other, different answers (A total of $9.33 \%$ ).

Figure 1 shows the answers concerning the motives of arrival of Hungarian tourists to Skorenovac, while Figure 2 provides a better overview of the number of tourists in relation to the ways in which they learned about this destination before making any travel decisions.

Graph 1. Travel motivations of tourists to visit Skorenovac

\section{Motives of arrival of Hungarian tourists to Skorenovac}

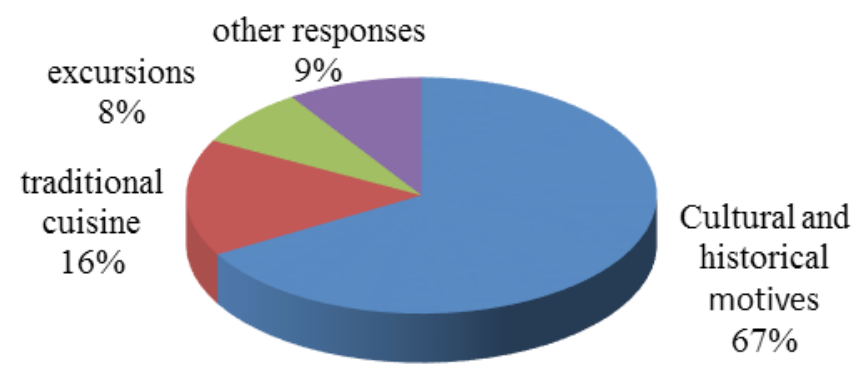

Source: authors, based on research

Based on the graph, it can be concluded that the cultural and historical motives were primary to influence the decision of the arrival of Hungarian tourists to the village of Skorenovac. Culture and tradition are strongly associated and this is the reason why the traditional cuisine is the second strongest motive for arrival of these tourists. Trips to Romania that are related to the history of the Hungarian population are the third motive for the tourists made a decision about going on this trip.

Figure 2 shows the answers to question No. 5, which referred to the promotion of Skorenovac before making travel decisions, that is, how the tourists found out about this village and what type of promotion made them choose this trip. 53 respondents $(70.66 \%)$ have declared that they found out about the trip from friends, $9(12 \%)$ via the emitting travel agencies, 8 respondents (10.67\%) learned about it from the internet, while one $(1.33 \%)$ respondent learned about it at the tourism fair in Budapest, and one $(1.33 \%)$ from an advertisement. Three respondents did not answer $(4 \%)^{4}$

4 Other primary values in tourism of Skorenovac such as accommodation, catering services, and human resources were not analyzed and compared because the village offers private accommodation only.

EP 2016 (63) 2 (601-615) 
Graph 2. Decision making before traveling

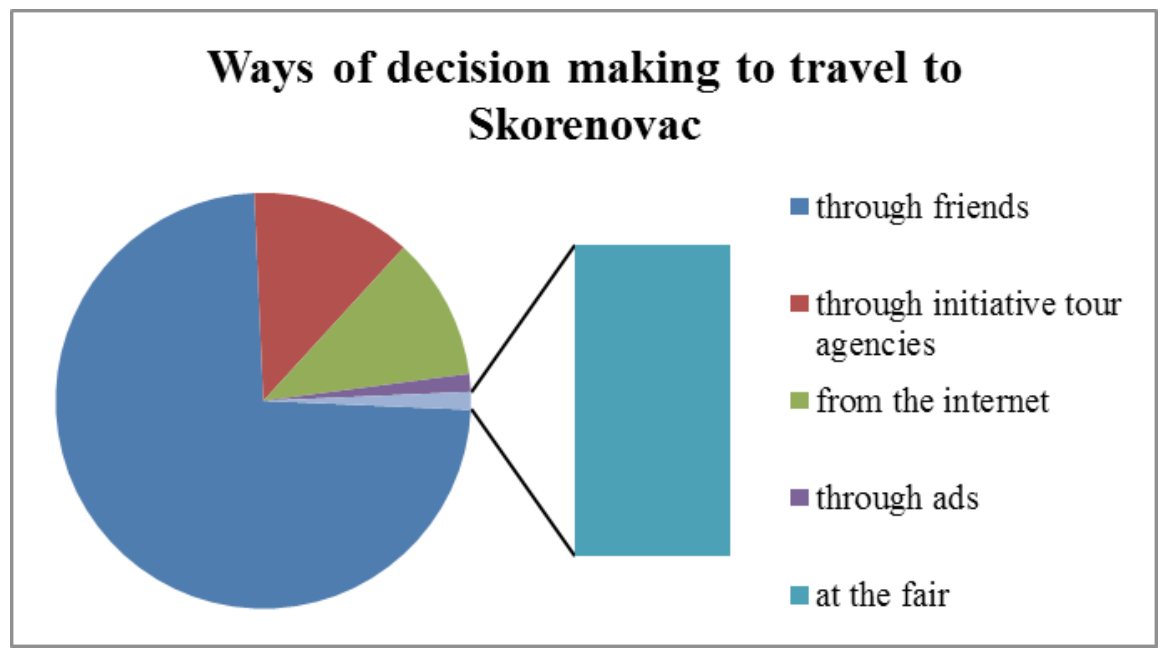

Source: authors, based on research

\section{Analysis of tourist expenditure in relation to age}

Auxiliary hypothesis was used which stated that the tourists' expenditure is age-related. From a total of 75 Hungarian tourists polled, most of them had visited Skorenovac for the first time.

With the help of the Kruskal-Wallis test, it was investigated whether the age actually affected the level of expenditure.

In Table 1 we compared the responses of tourists to question 15 (How much money did you spend in Skorenovac?) and Question 2 (How old are you?) in order to come to the conclusion whether the expenditure of tourists age-related.

Based on the results shown in Table 1, we conclude that the largest number of tourists who visited Skorenovac were aged 60 to 70. However, based on the sum of ranks, i.e. Kruskal-Wallis test results, it can be concluded that tourists aged 50 to 60 spent the most money.

Table 1. Results of Kruskal-Wallis test

\begin{tabular}{|l|l|l|l|}
\hline & Question \#2 & Number of tourists & Rank sum \\
\hline \multirow{4}{*}{ Question 15 } & $30-40$ & 12 & 29.63 \\
\cline { 2 - 4 } & $40-50$ & 12 & 38.00 \\
\cline { 2 - 4 } & $50-60$ & 15 & 41.67 \\
\cline { 2 - 4 } & $60-70$ & 36 & 39.26 \\
\cline { 2 - 4 } & Total: & $\mathbf{7 5}$ & \\
\hline
\end{tabular}

Source: authors, based on research 
Data from Table 2 was obtained with the help of the SPSS software; the values can be analyzed based on chi-square test, number of degrees of freedom and significance level (Asymp. Sig.).

Table 2. Interpretation of Kruskal-Wallis test

\begin{tabular}{|l|l|}
\hline Group variable & question 15 \\
\hline Chi-Square & 2.719 \\
\hline df & 3 \\
\hline Asymp. Sig. & .437 \\
\hline
\end{tabular}

Source: authors, based on research

Considering that the significance level is greater than 0.05 (in our case 0.437 ), it is an important indicator that there are significant statistical differences in the expenditure of tourists of different age groups. That is, we conclude that the tourists aged 50 to 60 spent the most. Relation between expenditure of tourists in relation to age is shown graphically on the basis of Figure 1.

Figure 1. Histogram of frequency distribution of tourists in Skorenovac in relation to the age structure

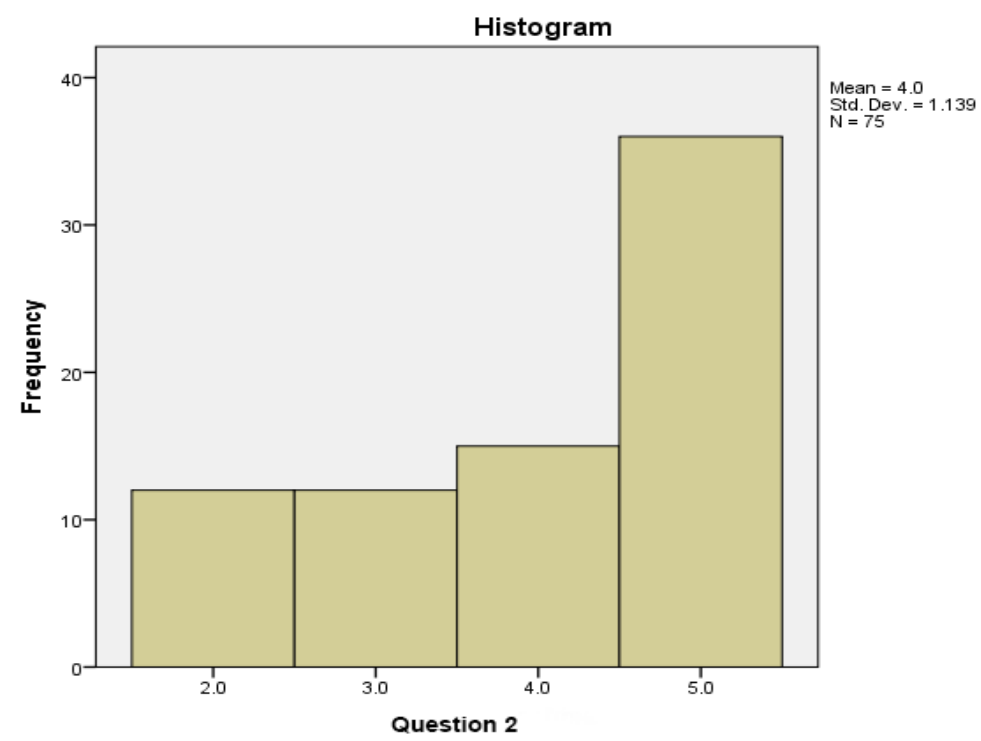

Source: authors, based on research

Based on the obtained data, we can conclude that the first auxiliary hypothesis that we tested can be accepted and we conclude that the expenditure of Hungarian tourists in Skorenovac is related to their age structure and the highest expenditure was realized by tourists aged 50 to 60 . 


\section{Analysis of the expenditure of tourists in relation to their level of education}

With the help of the Kruskal-Wallis test, the second auxiliary hypothesis from this paper was also tested: whether the level of education had an impact on the level of expenditure of tourists in Skorenovac. By comparing the responses of tourists to the question number 10 (degree of education), it was concluded that the most of the tourists who visited this settlement have education level that falls between college and university, which can be concluded on the basis of data from Figure 2.

Figure 2. Histogram of frequency distribution of tourists in Skorenovac in relation to the degree of their education

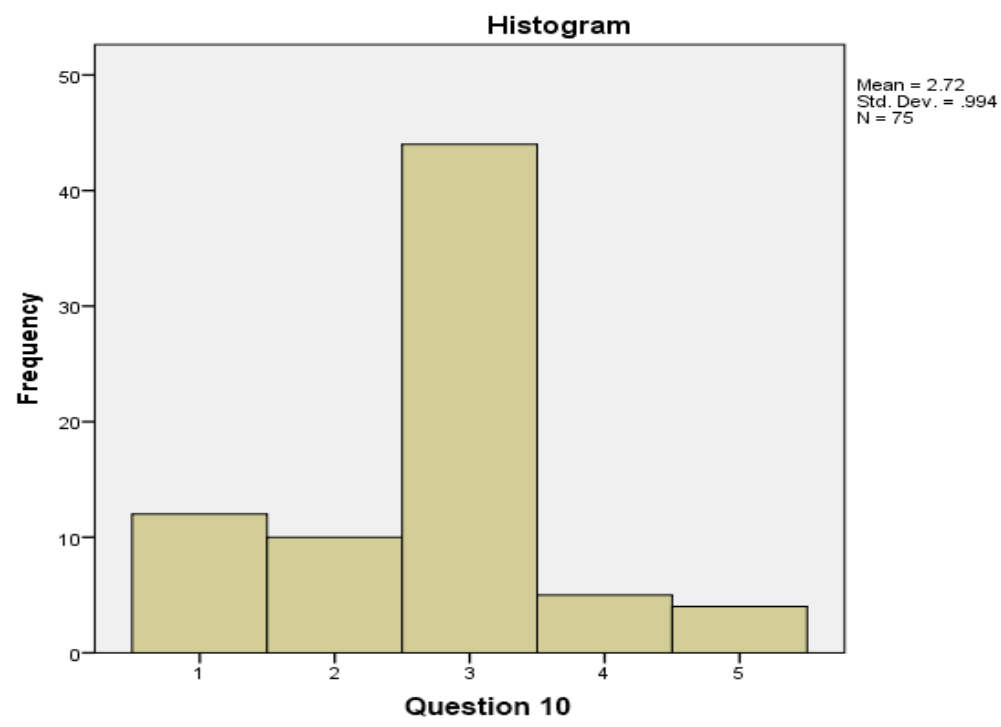

Source: authors, based on research

By applying the Kruskal-Wallis test and comparing the question \#15 (How much money did you spend on this trip) with question \#10 (degree of education) we conclude that the largest number of tourists (even 44) had college degree.

Table 3. Results of Kruskal-Wallis test

\begin{tabular}{|c|c|c|c|}
\hline & question 10 & N & Rank sum \\
\hline \multirow{4}{*}{ Question 15 } & 1 & 12 & 33.42 \\
\cline { 2 - 4 } & 2 & 10 & 32.50 \\
\cline { 2 - 4 } & 3 & 44 & 38.00 \\
\cline { 2 - 4 } & 4 & 5 & 43.50 \\
\cline { 2 - 4 } & 5 & 4 & 58.63 \\
\cline { 2 - 4 } & Total & 75 & \\
\hline
\end{tabular}

Source: authors, based on research 
However, by comparing the level of expenditure of tourists in relation to the degree of their education, we can conclude that the expenditure increases with the degree of education - highest expenditure was achieved by $\mathrm{PhDs}$, and there was for PhDs on this trip (this can be seen from Table 3). One explanation for this level of expenditure lies in the logical observation of facts, i.e. the most educated members of a society earn most, and consequently, spend most.

The tourists with master's degree have the second highest level of expenditure (five of them), while most tourists with the bachelor's degree are in the third place according to expenditure. These are followed by tourists with secondary education, and finally, tourists without qualification.

Table 4 (with chi-square test, number of degrees of freedom and significance level) reveals that the significance level is 0.203 , well over 0.05 .

Therefore, we can conclude that this is an important indicator of significant statistical differences in tourist expenditure with regard to age.

Hereby, we demonstrated that we reject the second auxiliary hypothesis we started with, which assumed that expenditure does not depend on the degree of education of tourists.

Table 4. Interpretation of Kruskal-Wallis test

\begin{tabular}{|l|l|}
\hline & question 15 \\
\hline Chi-Square & 5.946 \\
\hline df & 4 \\
\hline Asymp. Sig. & .203 \\
\hline
\end{tabular}

Source: authors, based on research

\section{Analysis of tourist expenditure in relation to gender}

The third auxiliary hypothesis was that the expenditure of tourists is not related to their gender.

Thanks to the application of Mann-Whitney $U$ test, two independent samples were tested: tourist gender (question \#3) and their expenditure (question \#15).

Table 5. The results of Mann-Whitney U test

\begin{tabular}{|l|l|l|l|l|}
\hline & question 3 & N & Average & Sum of Ranks \\
\hline \multirow{4}{*}{ question 15 } & 1.0 & 35 & 35.37 & 1238.00 \\
\cline { 2 - 5 } & 2.0 & 40 & 40.30 & 1612.00 \\
\cline { 2 - 5 } & Total & 75 & & \\
\hline
\end{tabular}

Source: authors, 2015.

The survey included 75 subjects, of which 35 men and 40 women. It was found that there is a statistically significant difference in expenditure between men and women, which is evident from the significance level of 0.29 .

EP 2016 (63) 2 (601-615) 
Table 6. Results of Man-Whitney U test

\begin{tabular}{|l|r|}
\hline & question 15 \\
\hline Mann-Whitney U & 608.000 \\
\hline Wilcoxon W & 1238.000 \\
\hline Z & -1058 \\
\hline Asymp. Sig. (2-tailed) & .290 \\
\hline
\end{tabular}

Source: authors, 2015.

Hence, based on the obtained results we can conclude that women are spending significantly more money as compared to men. Based on these results, we reject an auxiliary hypothesis which assumed that gender has no influence on the level of expenditure.

When it comes to the distribution of expenditure, with the help of the KolmogorovSmirnov test, it can be concluded that there are no extreme values in tourist expenditure.

Table 7. Extreme values of tourist expenditure in Skorenovac

\begin{tabular}{|c|c|c|c|c|c|c|}
\hline & \multicolumn{3}{|c|}{ Kolmogorov-Smirnov 1 } & \multicolumn{3}{c|}{ Shapiro-Wilk } \\
\cline { 2 - 7 } & Statistic & $\mathrm{df}$ & Sig. & Statistic & df & Sig. \\
\hline Question 15 & .247 & 75 & .000 & .859 & 75 & .000 \\
\hline
\end{tabular}

Source: authors, based on research

This can also be observed in Figure 3. During this period there was no extremely high expenditure of tourists in the village of Skorenovac. Most tourists spent about 200 euros including total costs: costs of accommodation, transport, food, daytrips, souvenir shopping etc.

Figure 3. Distribution of expenditure

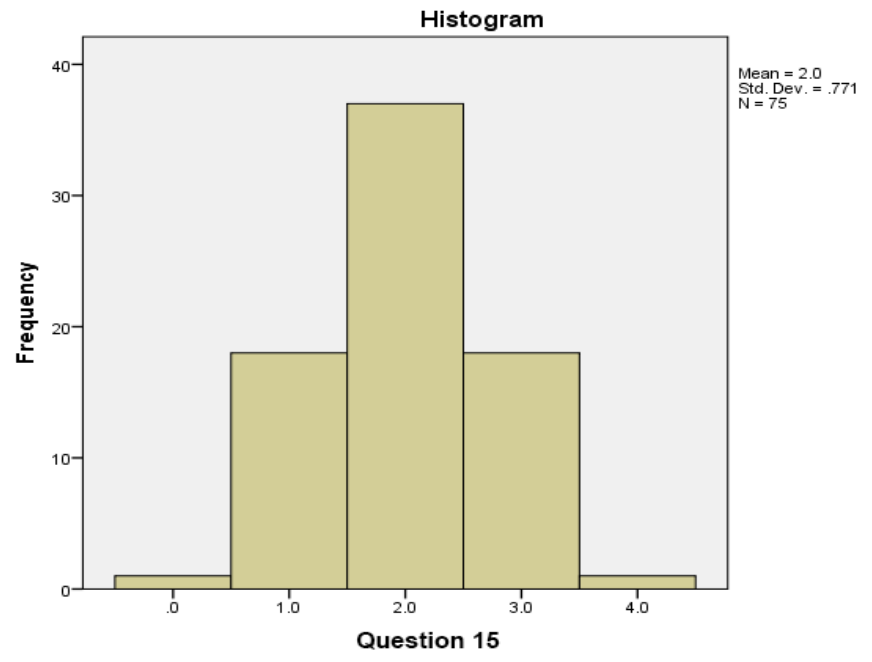

Source: authors, based on research 


\section{Assessment of the complete tourist offer of Skorenovac and normality of data distribution}

By taking advantage of descriptive statistics, 75 respondents were asked to indicate their satisfaction with the overall service and tourist offer of Skorenovac. The complete offer was rated very high: of 75 respondents, 73 gave opinion. 68 of them gave the highest mark (5), while 7 of them gave a rating of four. Two of the tourists did not respond.

Figure 4. Frequency of evaluation of satisfaction with the complete tourist offer of Skorenovac

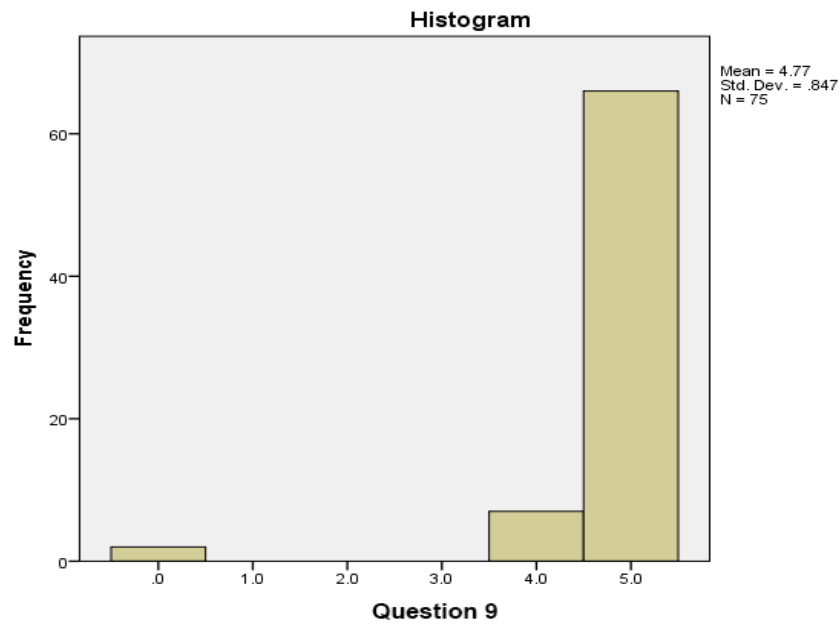

Source: authors, based on research

Based on Figure 4 we conclude that the largest number of Hungarian tourists was very pleased with the overall tourist offer during the two-day trip to Skorenovac.

\section{Conclusion}

The basic hypothesis in the work that socio-demographic characteristics affect the consumption of tourists, can be confirmed. Figure 1 shows the analysis of the responses of 75 tourists and shows that the majority of them were inspired to travel by the cultural and historical motives (67\%).

In addition to the main hypothesis, the paper also discusses three auxiliary hypotheses which should determine whether the consumption of tourists in Skorenovac is related to their age, gender and level of education.

By using specific statistical methods, we came to the following conclusions: in Skorenovac, where Hungarian tourists spend around 10,000 nights annually, the tourists aged 50 to 60 spend the most money. Based on this research, the first auxiliary hypothesis can be confirmed. 
The second auxiliary hypothesis which assumed that expenditure is not related to the degree of education, must be rejected, because research has shown that the most educated tourists spend the most money, which is not in accordance with the presumption. This can be explained by the fact that the most educated tourists have the highest earnings in their home country, and therefore spend the most. Since most respondents had college degree, the tourist offer at the destination shall be adapted to suit the largest group of tourists and their purchasing power.

The third tested hypothesis was related to gender of tourists and their spending. The starting point in this paper was the standpoint that the expenditure of tourists who visited Skorenovac is not related to their gender.

However, research has shown that women were spending considerably more money than men. It is therefore necessary to extend, adapt and modernize the offer to raise the interest of women to spend even more and to continue the trend of increasing expenditure. Also, it is important to examine what products and services would raise interest in men to spend more money. These products and services should be made available to them.

Tourist destination is a set of attractions, infrastructure, equipment, and service providers in precisely bounded geographical areas in which specific activities contribute to the overall visitor experience of a destination (Čerović, 2009).

In modern market economies, especially in those which tend to build market mechanisms, marketing consulting is the result of a need for adequate and timely market information, which has become a key factor of a business's success (Cvijanović et al., 2015).

The research also showed that Vojvodina can be a competitive and attractive tourist destination in specific segments of offer, and the subject of interest by tourists from the region.

The development of rural tourism includes the participation and cooperation of different participants with diverse internal and external characteristics (Čikić et al., 2015).

However, it takes a lot of changes, in both micro and macro levels in the country in order to increase the number of visits, and consequently, the consumption of tourists; for example, greater control of all institutions and individuals involved in the process of providing services is needed: increasing quality of services, issuing fiscal receipts, registration of guests, paying taxes and so on.

In the context of multifunctionality the rural tourism, which allows to satisfy the growing interest towards the natural heritage and rural culture by modern society that, with the advent of new technologies and hectic lifestyle, it is deprived of these values is increasingly affirming. This contribute to reduce the exodus of population from rural areas and to create job opportunities, promoting the socio-economic development of disadvantaged areas (Sgroi et al., 2014).

On the other hand, the village of Skorenovac is an example of a good practice (data has showed that the largest number of tourists came based on word-of-mouth 
recommendations) on how to raise the interest of foreign tourists to visit our country, despite the poor touristic infrastructure, reduced diversity in terms of catering services, accommodation, souvenirs, daytrips and ways of bringing tourists.

However, despite the deprived tourist offer, the largest number of Hungarian tourists rated the overall tourist offer of Skorenovac with the highest mark. Nevertheless, the question is whether the demand for this destination will exist in the future and whether the destination as such is sustainable. The reason is the lack of activities, lack of investments and non-expansion of the tourist offer.

For the rural tourism sector to thrive, local inhabitants must become entrepreneurs and develop and promote their own enterprises (Pena et al., 2013).

Strategy without tactics is the slowest route to victory. Tactics without strategy is the noise before defeat (Kaplan, Norton, 2010).

\section{References}

1. Arch G. Woodside, Martin D. (2009): Tourism Management, Analysis, Behavior and Strategy (ISBN 978-1-84593-323-4). Cab International.

2. Areavey R.M, Donagh J.M. (2011): Sustainable Rural Tourism: Lessons for Rural Development, Sociologia Ruralis. The European Society for Rural Sociology (ESRS), vol. 51, no. 2, pp. 175-194.

3. Baoren S. (2011): Rural Tourism in China. Tourism Management, Volume 32, Issue 6, pp. 1438-1441.

4. Bošković T., Tomić R., Tomić D. (2013): Potentional and Limitations for the Development of Rural Tourism in Vojvodina. Economics of Agriculture, IAE Belgrade, vol. 60, no. 1, pp. 103-111.

5. Cvijanović D., Mihajlović B., Čavlin M., Čavlin G. (2015): Impact of Marketing Consulting on Performances of Agrarian Clusters in Serbia. Sustainability, 2015, vol. 7, no. 2, pp. 1099-1115.

6. Čerović S. (2009): Strategijski menadžment u turizmu (ISBN: 978-86-7912177-6). Univerzitet Singidunum, Beograd.

7. Čikić J., Petrović M., Đurđev B. (2015): Diffusion of Knowledge and Rural Tourism Development - Example of Vojvodina. Economics of Agriculture, no. 1, p. 123-137.

8. Derek H., Kirkpatrick I., Mitchell M. (2005): Rural Tourism and Sustainable Business (ISBN 1-84541-012-2). Cromwell Press, Great Britain.

9. Garson D. (2012): Testing Statistical Assumption. North Carolina State University, Statistical Publishing Associates. (ISBN-10: 1626380333)

10. Goeldner Ch.R., Ritchie J.R.B. (2009): Tourism: Principles, Practices, Philosophies (ISBN 978-1118071779). John Wiley \& Sons, New Jersey.

11. Grossman E. (2013): Kurokawa No: Shaping the Image and Perception of 
Japan's Folk Traditions, Performing Arts and Rural Tourism (ISBN 9789004223349). Global Oriental.

12. Kaplan R.S., Norton D.P. (2008): The Execution Premium: Linking Strategy to Operations for Competitive Advantage (ISBN 978-1422121160). Harvard Business Review Press.

13. Milićević S., Podovac M., Čavlin M. (2015): Resources for Development of the Rača Municipality as a Rural Tourism Destination, Economics of Agriculture. Balkan Scientific Association of Agrarian Economists, Institute of Agricultural Economics, vol. 62, no. 3, pp. 751-765, Belgrade, Serbia.

14. Mrkša, M., Gajić, T. (2014): Opportunities for Sustainable Development of Rural Tourism in the Municipality of Vrbas. Economics of Agriculture, IAE Belgrade, vol.61, no.1, pp. 163-167.

15. Muhi, B., Jovanović, D. (2012): Rural Tourism as a Factor of Integral and Sustainable Development of Rural Areas and Villages of Serbia and Vojvodina. Herald Journal of Geography and Regional Planning vol. 1, no. 2, pp. 14-18.

16. Pesonen, J., Komppula, R., Peters M., (2011): Understanding Relationship Between Push and Pull Motivations in Rural Tourism. Tourism Review, vol. 66, no. 3, pp. 32-49.

17. Polo-Pena AI, Olmo J.Ch., Jamilena F.A.D., Molina R.A.M. (2015): Market Orientation Adoption among Rural Tourism Enterprises: The Effect of the Location and Characteristics of the Firm. International Journal of Tourism Research, vol. 17, no. 1, pp. 54-65.

18. Popović, V., Katić, B., Savić, M. (2011): Ruralni razvoj u Srbiji i lokalne zajednice. Ekonomika poljoprivrede, IAE Belgrade, vol. 63, no. 1, pp. 33-44.

19. Prentović R., Kurjački A., Cvijanović D. (2012): Hunting in Rural Areas of Bačka. Economics of Agriculture, IAE Belgrade, vol. 59, no.3, pp. 385-400.

20. Richards G., Munster W. (2010): Cultural Tourism Research Methods (ISBN 978-1845935184). Cabi International, USA.

21. Sgroi F., Trapani A.M., Testa R., Tudista R. (2014): The Rural Tourism as Development Opportunity of Farms. The Case of Direct Sales in Sicily. American Journal of Agricultural and Biological Sciences vol. 9, no. 3, pp. 407-419.

22. Štetić S., Pavlović S., Stanić S., Šimičević D. (2014): Dimensions of Integrated Tourism-Case Studies of Selected Villages in the Serbia-Romania Border Area. Journal of Settlements and Spatial Planning, Special Issue 3, pp. 81-88.

23. George W.E., Mair H., Reid D.G. (2009): Rural Tourism Development: Localism and Cultural Change (ISBN 978-1845410995). Channel View Publications. 


\title{
UTICAJ SOCIO-DEMOGRAFSKIH KARAKTERISTIKA NA POTROŠNJU MAĐARSKIH TURISTA U SELU SKORENOVAC
}

\author{
Živana Krejič́, Slobodan Čerovićc ${ }^{6}$, Snežana Milićevič ${ }^{7}$
}

\begin{abstract}
Sažetak
Razvoj seoskog turizma u Vojvodini utiče na opstanak sela i egzistenciju njegovog stanovništva. Uprkos brojnim problemima sa kojima se vojvođanska sela suočavaju, primer dobre prakse predstavlja selo Skorenovac u opštini Kovin, u Banatu.

Lokalna kultura, običaji i legende iz daleke prošlosti, jedinstven način života stanovništva ovog sela, predstavljaju primarne motive koji su razlog dolaska turista $i$ koji utiču na razvoj seoskog turizma.

Cilj ovog istraživanja bio je da utvrdi da li postoje određene razlike u potrošnji mađarskih turista u selu Skorenovac, u odnosu na starost, nivo obrazovanja i pol.

Rezultati istraživanja mogu poslužiti kao inspiracija i podsticaj seoskim domaćinstvima za praćenje socio-demografskih karakteristika turista u formiranju turističke ponude sa ciljem povećavanja profita.
\end{abstract}

Ključne reči: socio-demografske karakteristike, seoski turizam, mađarski turisti, Vojvodina, potrošnja

5 Master Živana Krejić, doktorand, Univerzitet Singidunum, Fakultet za turistički i hotelijerski menadžment, Danijelova ulica br. 32, Beograd, Srbija, Telefon: +381 6690078 78; E-mail: zkrejic@yahoo.com

6 Redovni profesor, dr Slobodan Čerović, Univerzitet Singidunum, Beograd, Srbija, Telefon: +381 1130932 10, E-mail: scerovic@singidunum.ac.rs

7 Docent, dr Snežana Milićević, Univerzitet u Kragujevcu, Fakultet za hotelijerstvo i turizam u Vrnjačkoj banji, Vojvođanska ulica br. 5A, 36210 Vrnjačka Banja, Srbija, Telefon: + 381 3651500 24, E-mail: snezana.milicevic@kg.ac.rs

EP 2016 (63) 2 (601-615) 